\title{
Macroalgal communities of the Suez Canal after the recent improvement of marine habitats
}

\author{
Islam M. El-Manawy \\ Department of Botany, Faculty of Science, \\ Ismailia, Suez Canal University.
}

El-Manawy, I. M. 2001. Macroalgal communities of the Suez Canal after the recent improvement of marine habitats. Taeckholmia 21(2): 205-219.

The macroalgal communities of the Suez Canal were seasonally investigated at 16 sites during 1996 and 2000 . A hundred and twenty eight taxa including 15 new records were identified. The recent reduction of navigation and urbanization works resulted in an increase in species richness (42 species) and algal forms.

Distribution pattern, seasonal variation, and algal zonation were also examined. All were intensely regulated by substrate, space, depth, light, and water movement during the passage of ships. Sites were clustered, on the basis of species co-occurrence, into five groups, suggesting division of the Suez Canal into four biological sectors. The hard substrata supported distinct algal zones. Cladophoropsis zollingeri and Bangia fuscopurpurea characterized the littoral zone. A rich algal community dominated the infralittoral at a depth of 30-150 cm, while a few red species with Caulerpa racemosa were found deeper. Competition for space in some sites was evident by presence of 61 epiphytic macroalgae. A half of these were also found on hard substrata when the space was available.

Algal succession in the canal during the past century was also discussed in the light of environmental changes. Algal succession could have passed through four stages; including the establishment of pioneers until 1924, the maturity to a climax sometime before1953, degradation of the climax due to navigation and urbanization constructions, and the reestablishment of the climax with the recent improvement in algal habitats.

Key words: Egypt, macroalgae, marine habitat, Red Sea, succession, Suez Canal.

\section{Introduction}

Studies on the macroalgae inhabiting the Suez Canal date back to the beginning of $20^{\text {th }}$ century when Muschler (1908) recorded 8 species of red algae. Lyle (1930) reported on 24 species obtained by the Cambridge Expedition in 1924. Lami (1932) reported on 9 algae collected from the Great Bitter Lake by Gruvel in 1932. Beets (1953) encountered 4 species during his study of the sediments in the Great Bitter Lake. Lipkin (1972) published a list containing 55 species of macroalgae. Aleem (1980) published a list containing 110 species of macroalgae collected along the whole canal in 1953.

Stress on the macroalgae of the canal had been increased between 1973 and 1985 due to the widening and deepening works in the navigation channel (El-Manawy, 1992). This was accompanied with some other works, such as building of ports, harbors, jetties, and revetments. Moreover, the construction of Abu Sultan power plant in 1983, private houses and hotels near the shore and the discharge of their effluents into the canal threatened the biota. The macroalgae in different parts of the canal have been, thus, rechecked throughout a number of publications (e.g., Farghaly, 1985; Farghaly et al., 1988; and El-Manawy, 1987, 1992).

At the end of 1995, navigation and its accompanied works have been reduced; treatment plants for sewage and other effluents were constructed and industrialization and urbanization effluents are by now very limited. This work aimed to study the macroalgal 
flora after this recent improvement in algal habitats. The objective was also to give an idea about the succession of macroalgal flora throughout the past years of the canal existence.

\section{Study area}

The Suez Canal lies between $29^{\circ} 55^{\prime}$ and $31^{\circ} 25^{\prime} \mathrm{N}$ and $32^{\circ} 15^{\prime}$ and $32^{\circ} 35^{\prime} \mathrm{E}$ (Figure 1). Its length is $162.5 \mathrm{~km}$. It passes throughout the Bitter Lakes, Lake Timsah and Lake Manzala. The canal, at its opening in 1869, was 8-m deep and 44-52 m wide. It has been widened and deepened several times, as an answer to size and drought of ships. Today, after its last development in 1985, the canal has a width of 250-365 m and 25-m depth. Four side shipping lanes were added to the canal at Kabrit, Deversoir, el-Ballah and Ras el-Ish.

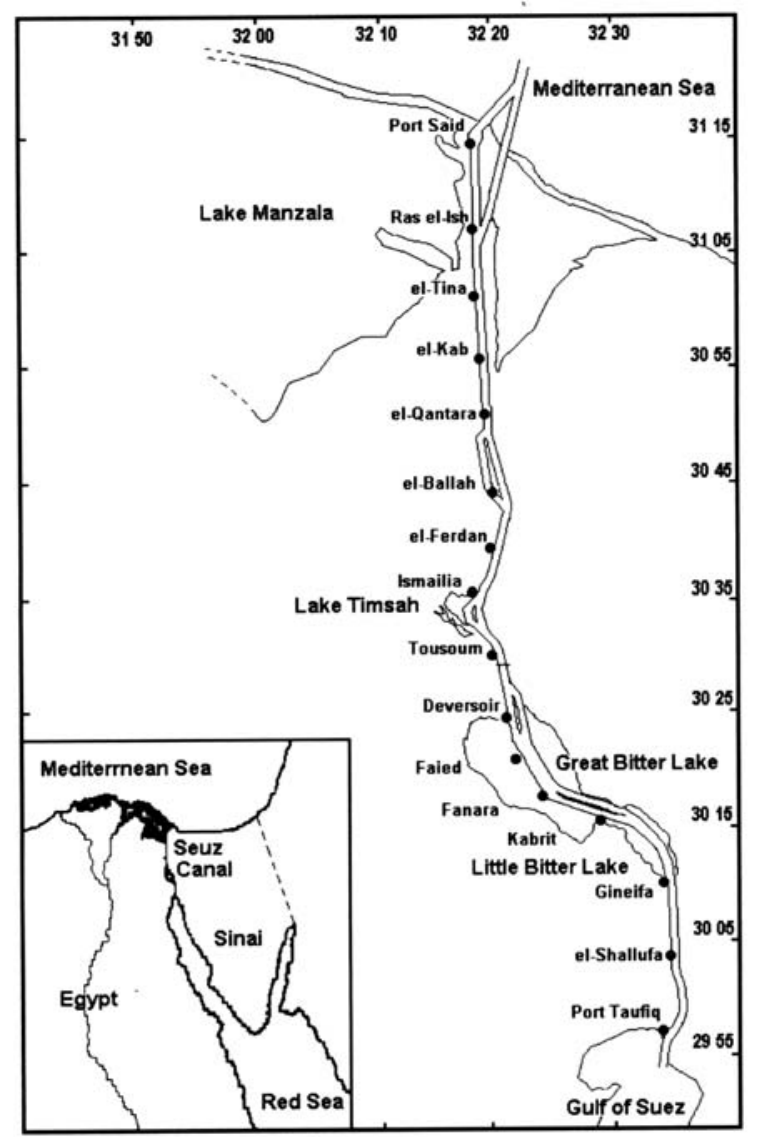

Figure 1. The Suez Canal and the investigated sites (black dots) from Port Said to Port Taufiq. 
The Great Bitter Lake is the largest water body, containing $85 \%$ of the canal water. It had been hyper-saline due to the dissolution of a salt-bed of 13.3-m thickness (de Lesseps, 1876). Thus, the lake had acted for a long time as a barrier for species migration between the two adjacent seas (Por, 1978). The salt-bed had been gradually dissolved and by1965, no trace of salt was found and the water salinity was 43-48\% (Miller and Munns, 1974). El-Manawy (1992) gave a salinity of 46 \% in summer and $42 \%$ in winter for the Bitter Lakes. El-Soubaky (1995) gave very fluctuated salinities (13-46 \%o) measured in 1992-93 at several sites along the canal. The current in the canal has a northward direction (El-Sabh, 1969), sets southward during only August and September. The wind is northeast and seems to influence only the immediate surface waters (Wüst, 1934).

The lakes are almost sand-locked with a concrete pavement at the area through which the canal leads. The natural zones of the shore are almost flat, composed predominantly of mudflats and sands. Stones, pebbles and ship wracks are distributed on these zones and on the islets between the canal's bypasses. From the shoreline, the depth gradually increases to approximately 10 meters. An anchorage area, of approx. 13-20 m water depth, is found in the central part of the Great Bitter Lake. It contains many mooring posts made-up of concrete. Other hard substrata in the canal are the extensive navigation installations (e.g., marina and harbor walls, canal embankments, and pilings).

\section{Materials and methods}

The algal collections were performed seasonally during 1996 and 2000. Sixteen sites were chosen on the Suez Canal for algal sampling (Figure 1). The water salinity was measured at seasonal intervals using a portable refractometer. Algal samples were intensively collected from the eastern and western shores, from islets and mooring posts, on stones, pebbles, boulders and ship wracks, as well as from other hard substrata of marinas, harbor walls, canal embankments, and pilings. Algae were preserved as herbaria or in $4 \%$ formalin-seawater solution for further identification. Records of site, depth, habitat types, and the general ecological conditions are included with all voucher specimens. Identification of the species was carried out using standard references (e.g., Aleem, 1993; Børgesen, 1920, 1925-36, 1944-57; Dawson, 1962; Feldmann, 1940; Jaasund, 1977). In analysis of algal data, the sites were clustered using STATISTICA package, version 4.3, euclidean distance as a similarity coefficient, and the cluster option was complete linkage. For algal succession, a similarity matrix for the presence and absence data was generated using Jaccard coefficient (1908).

\section{Results and discussion}

A list of 128 taxa, including 37 green, 22 brown and 69 red species were identified in the present work (Table 1). The total number of taxa was 115 species during 1996, reached a magnitude of 127 species during 2000. Comparing this list with the last work carried out along the whole canal length (Farghaly, 1985) indicates an increase of 42 species. This increase in species richness may suggest an amelioration of algal habitats after the reduction of navigation and urbanization effluents. Measured values of salinity during this study were more stable than those recorded by El-Soubaky (1995) in 1992-93. The present salinity was measured as 27-31 \%o at Port Said, 40-45 \%o at el-Qantara, 27-30 \%о at Ismailia, 39-42 \%o at Deversoir, 42-45 \%o at Kabrit, and 37-40 \%o at Port Taufiq. El- 
Soubaky (1995) gave very fluctuated salinities (13-46 \%o), owning these fluctuations to the effects of domestic and agricultural effluents discharged in the canal near Port Said, Lake Timsah and Faied.

Table 1. Algal records on different substrata during four seasons in 1996 and 2000. Asterisked species are the new records. SP, spring; SU, summer; AU, autumn; WN, winter. S, sand; C, concrete; B, boulders; W, wracks; E, epiphytic.

\begin{tabular}{|c|c|c|c|c|c|c|c|c|c|c|c|}
\hline Algal records & $\mathbf{Y e}$ & ars & & Sea & ons & & & & ostr & & \\
\hline Chlorophyta & 1996 & 2000 & SP & SU & AU & $\mathrm{WN}$ & $\mathrm{S}$ & $\mathrm{C}$ & $\mathrm{B}$ & $\mathrm{W}$ & $\mathrm{E}$ \\
\hline Acetabularia calyculus Quoy et Gaimard & 1 & 1 & 1 & 1 & 0 & 0 & 1 & 0 & 0 & 0 & 0 \\
\hline Avrainvillea amadelpha (Montagne) Gepp & 1 & 1 & 1 & 0 & 0 & 1 & 1 & 0 & 0 & 0 & 0 \\
\hline Bryopsis plumosa C. Agardh & 1 & 1 & 1 & 1 & 0 & 1 & 0 & 1 & 1 & 1 & 0 \\
\hline Caulerpa lentillifera $J$. Agardh & 1 & 1 & 1 & 0 & 0 & 1 & 1 & 0 & 0 & 0 & 0 \\
\hline Caulerpa mexicana Donder ex Kützing & 1 & 1 & 1 & 0 & 0 & 1 & 1 & 0 & 0 & 0 & 0 \\
\hline Caulerpa racemosa (Forsskål) J. Agardh & 1 & 1 & 1 & 1 & 1 & 1 & 1 & 0 & 0 & 0 & 0 \\
\hline Caulerpa scalpelliformis (Brown) J. Agardh & 1 & 1 & 1 & 1 & 0 & 1 & 1 & 0 & 0 & 0 & 0 \\
\hline Caulerpa sertularioides (Gmelin) Howe & 1 & 1 & 1 & 1 & 1 & 1 & 1 & 0 & 0 & 0 & 0 \\
\hline Caulerpa taxifolia (Vahl) C. Agardh & 1 & 1 & 1 & 1 & 0 & 0 & 1 & 0 & 0 & 0 & 0 \\
\hline Caulerpa webbiana Montagne & 1 & 1 & 1 & 1 & 0 & 0 & 1 & 0 & 0 & 0 & 0 \\
\hline Chaetomorpha aerea (Dillwyn) Kützing & 0 & 1 & 1 & 0 & 0 & 1 & 0 & 1 & 0 & 0 & 1 \\
\hline Chaetomorpha indica (Kützing) Kützing & 1 & 1 & 1 & 1 & 1 & 1 & 0 & 1 & 0 & 1 & 1 \\
\hline Chaetomorpha linum (Muller) Kützing & 1 & 1 & 1 & 1 & 0 & 1 & 0 & 1 & 0 & 0 & 1 \\
\hline Cladophora albida (Hudson) Kützing & 1 & 1 & 0 & 1 & 1 & 0 & 0 & 1 & 0 & 1 & 1 \\
\hline Cladophora crystallina (Roth) Kützing & 1 & 0 & 1 & 1 & 1 & 1 & 0 & 1 & 0 & 1 & 1 \\
\hline Cladophora prolifera (Roth) Kützing & 1 & 1 & 1 & 1 & 1 & 1 & 0 & 1 & 0 & 0 & 1 \\
\hline Cladophora rupestris (Linnaeus) Kützing & 1 & 1 & 1 & 1 & 1 & 1 & 0 & 1 & 0 & 0 & 0 \\
\hline Cladophora sericea (Hudson) Kützing & 1 & 1 & 1 & 1 & 0 & 0 & 0 & 1 & 0 & 0 & 1 \\
\hline Cladophoropsis zollingeri (Kütz.) Børgesen & 1 & 1 & 1 & 1 & 1 & 1 & 0 & 1 & 0 & 0 & 1 \\
\hline Codium tomentosum Kützing & 1 & 1 & 1 & 0 & 0 & 1 & 0 & 1 & 0 & 0 & 0 \\
\hline Derbesia lamourouxii (J. Agardh) Solier & 1 & 1 & 1 & 1 & 0 & 1 & 0 & 1 & 1 & 1 & 0 \\
\hline * Dictyosphaeria cavernosa (Fors.) Børg. & 0 & 1 & 0 & 0 & 0 & 1 & 0 & 0 & 0 & 0 & 1 \\
\hline Enteromorpha clathrata (Roth) J. Agardh & 1 & 1 & 1 & 1 & 1 & 1 & 0 & 1 & 1 & 0 & 1 \\
\hline Enteromorpha compressa (Linn.) Greville & 1 & 1 & 1 & 1 & 0 & 1 & 0 & 1 & 1 & 1 & 0 \\
\hline Enteromorpha flexuosa (Wulfen) J. Agardh & 1 & 1 & 1 & 1 & 0 & 0 & 0 & 1 & 1 & 1 & 1 \\
\hline Enteromorpha intestinalis (Linn.) Greville & 1 & 1 & 1 & 1 & 1 & 1 & 0 & 1 & 1 & 1 & 1 \\
\hline Enteromorpha prolifera (Muller) J. Agardh & 1 & 1 & 1 & 1 & 1 & 1 & 0 & 1 & 1 & 1 & 1 \\
\hline * Halimeda monile (Ellis et Sol.) Lamour. & 0 & 1 & 0 & 0 & 0 & 1 & 1 & 0 & 0 & 0 & 0 \\
\hline * Halimeda opuntia (Linnaeus) Lamouroux & 1 & 1 & 1 & 1 & 0 & 0 & 1 & 0 & 0 & 0 & 0 \\
\hline Halimeda tuna (Ellis et Sol.) Lamouroux & 1 & 1 & 0 & 0 & 0 & 1 & 1 & 0 & 0 & 0 & 0 \\
\hline Phaeophila dendroides (Crouan) Batters & 1 & 1 & 1 & 0 & 0 & 1 & 0 & 0 & 0 & 0 & 1 \\
\hline Rhizoclonium kochianum Kützing & 1 & 1 & 1 & 1 & 0 & 1 & 1 & 1 & 0 & 1 & 0 \\
\hline Udotea argentea Zanardini & 1 & 1 & 1 & 1 & 1 & 0 & 1 & 0 & 0 & 0 & 0 \\
\hline Ulva fasciata Delile & 1 & 1 & 0 & 0 & 0 & 1 & 0 & 1 & 1 & 1 & 0 \\
\hline Ulva lactuca Linnaeus & 1 & 1 & 1 & 1 & 1 & 1 & 0 & 1 & 1 & 0 & 1 \\
\hline Ulva rigida C. Agardh & 1 & 1 & 1 & 0 & 0 & 1 & 0 & 1 & 1 & 0 & 0 \\
\hline Valonia aegagropila C. Agardh & 1 & 1 & 1 & 0 & 0 & 1 & 0 & 0 & 0 & 0 & 1 \\
\hline Phaeophyta & & & & & & & & & & & \\
\hline Colpomenia sinuosa Derbes et Solier & 1 & 1 & 1 & 1 & 0 & 1 & 0 & 0 & 0 & 0 & 1 \\
\hline Cystoseira myrica (Gmelin) C. Agardh & 1 & 1 & 1 & 1 & 1 & 1 & 0 & 1 & 0 & 0 & 0 \\
\hline Cystoseira trinodis (Forsskål) C. Agardh & 1 & 1 & 0 & 0 & 0 & 1 & 0 & 1 & 0 & 0 & 0 \\
\hline Dictyota ciliolata Kützing & 1 & 1 & 0 & 0 & 0 & 1 & 0 & 1 & 1 & 1 & 1 \\
\hline Dictyota dichotoma (Hudson) Lamouroux & 1 & 1 & 1 & 1 & 1 & 1 & 0 & 1 & 0 & 0 & 1 \\
\hline Dictyota indica Sonder ex Kützing & 1 & 1 & 1 & 1 & 1 & 1 & 0 & 1 & 0 & 0 & 1 \\
\hline Ectocarpus elachistaeformis Heydrich & 0 & 1 & 0 & 0 & 0 & 1 & 0 & 1 & 0 & 0 & 0 \\
\hline Ectocarpus siliculosus (Dillwyn) Lyngbye & 1 & 1 & 0 & 0 & 0 & 1 & 0 & 1 & 0 & 0 & 0 \\
\hline Feldmannia irregularis (Kützing) Hamel & 1 & 1 & 1 & 1 & 1 & 1 & 0 & 1 & 0 & 0 & 0 \\
\hline
\end{tabular}


Macroalgal communities of the Suez Canal

Table 1. Continued

\begin{tabular}{|c|c|c|c|c|c|c|c|c|c|c|c|}
\hline Giffordia indica (Sond.) Papenf. et Chihara & 1 & 1 & 1 & 0 & 0 & 0 & 0 & 1 & 0 & 1 & 0 \\
\hline Giffordia mitchellae (Harvey) Hamel & 1 & 1 & 1 & 1 & 0 & 1 & 0 & 1 & 0 & 1 & 0 \\
\hline Halopteris scoparia (Linnaeus) Sauvageau & 1 & 1 & 1 & 0 & 0 & 0 & 0 & 1 & 0 & 0 & 0 \\
\hline * Hormophysa triquetra (C. Ag.) Kützing & 1 & 1 & 1 & 0 & 0 & 1 & 0 & 1 & 0 & 0 & 0 \\
\hline Hydroclathrus clathratus (C. Agardh) Howe & 0 & 1 & 0 & 0 & 0 & 1 & 0 & 0 & 0 & 0 & 0 \\
\hline Padina pavonica (Linnaeus) Thivy & 1 & 1 & 1 & 1 & 1 & 1 & 0 & 1 & 1 & 0 & 1 \\
\hline Sargassum dentifolium (Turner) C. Agardh & 1 & 1 & 1 & 1 & 1 & 1 & 0 & 1 & 0 & 0 & 0 \\
\hline Sargassum forsskalii (Mertens) Papenfuss & 1 & 1 & 1 & 1 & 0 & 1 & 0 & 1 & 0 & 0 & 0 \\
\hline * Sargassum ilicifolium (Turner) C. Agardh & 1 & 1 & 0 & 0 & 0 & 1 & 0 & 1 & 0 & 0 & 0 \\
\hline Sargassum subrepandum (Fors.) C. Ag. & 1 & 1 & 1 & 1 & 1 & 1 & 0 & 1 & 0 & 0 & 0 \\
\hline Scytosiphon lomentaria (Lyng.) Endlicher & 1 & 1 & 1 & 0 & 0 & 1 & 0 & 1 & 0 & 1 & 0 \\
\hline Sphacelaria furcigera Kützing & 1 & 1 & 1 & 1 & 1 & 0 & 0 & 1 & 0 & 0 & 0 \\
\hline * Zonaria schimperi Kützing & 0 & 1 & 0 & 0 & 0 & 1 & 1 & 0 & 0 & 0 & 0 \\
\hline Rhodophyta & & & & & & & & & & & \\
\hline Acanthophora najadiformis (Delile) Papen. & 1 & 1 & 1 & 1 & 1 & 1 & 0 & 1 & 1 & 1 & 0 \\
\hline Acrochaetium robustum Børgesen & 1 & 1 & 1 & 1 & 1 & 1 & 0 & 0 & 0 & 0 & 1 \\
\hline * Asparagopsis taxiformis (Delile) Trevisan & 0 & 1 & 0 & 1 & 0 & 1 & 0 & 1 & 0 & 0 & 0 \\
\hline Asterocystis ornata (C. Agardh) Hamel & 1 & 1 & 0 & 0 & 0 & 1 & 0 & 0 & 0 & 0 & 1 \\
\hline Bangia fuscopurpurea (Dillwyn) Lyngbye & 1 & 1 & 1 & 1 & 1 & 1 & 1 & 1 & 1 & 0 & 0 \\
\hline Centroceras clavulatum (C. Ag.) Montagne & 1 & 1 & 0 & 1 & 1 & 0 & 0 & 1 & 0 & 0 & 1 \\
\hline Ceramium gracillimum (Küt.) Grif et Harvey & 1 & 1 & 1 & 1 & 1 & 0 & 0 & 1 & 0 & 1 & 1 \\
\hline Ceramium procumbens Stech. Et Gardn. & 1 & 1 & 1 & 1 & 0 & 0 & 0 & 0 & 0 & 0 & 1 \\
\hline Ceramium taylorii Dawson & 1 & 1 & 1 & 1 & 1 & 1 & 0 & 0 & 0 & 0 & 1 \\
\hline Ceramium tenerrimum (Mertens) Okamura & 1 & 1 & 1 & 1 & 0 & 1 & 0 & 0 & 0 & 0 & 1 \\
\hline Ceramium tenuissimum (Roth) J. Agardh & 1 & 1 & 0 & 0 & 0 & 1 & 0 & 0 & 0 & 0 & 1 \\
\hline Champia parvula (J. Agardh) J. Agardh & 1 & 1 & 0 & 0 & 0 & 1 & 0 & 1 & 0 & 0 & 1 \\
\hline * Champia tripinnata Zanardini & 1 & 1 & 0 & 0 & 0 & 1 & 0 & 0 & 0 & 0 & 1 \\
\hline Chondria collinsiana Howe & 1 & 1 & 1 & 1 & 1 & 1 & 0 & 0 & 0 & 0 & 1 \\
\hline Chondria dasyphylla (Wood.) C. Agardh & 1 & 1 & 1 & 1 & 0 & 1 & 0 & 1 & 1 & 1 & 0 \\
\hline Chondria repens Børgesen & 1 & 1 & 1 & 1 & 0 & 0 & 0 & 1 & 1 & 0 & 0 \\
\hline Chondria tenuissima (Good. Wood.) C. Ag. & 1 & 1 & 1 & 1 & 1 & 1 & 0 & 1 & 1 & 0 & 0 \\
\hline * Corallina tenella (Kutzing) Heydrich & 0 & 1 & 0 & 0 & 1 & 0 & 0 & 0 & 0 & 0 & 1 \\
\hline Crouania attenuata (C. Agardh) J. Agardh & 1 & 1 & 1 & 1 & 0 & 1 & 1 & 1 & 0 & 0 & 1 \\
\hline Dasya flocculosa Zanardini & 1 & 1 & 0 & 1 & 0 & 0 & 0 & 1 & 0 & 0 & 0 \\
\hline * Dermatolithon cystoseirae (Hauck) Huve & 1 & 1 & 1 & 1 & 1 & 1 & 0 & 0 & 0 & 0 & 1 \\
\hline Dermatolithon geometricum (Lem) Lemoin & 1 & 1 & 0 & 1 & 1 & 0 & 0 & 1 & 0 & 0 & 1 \\
\hline Digenea simplex (Wulfen) C. Agardh & 1 & 1 & 1 & 0 & 0 & 1 & 0 & 1 & 0 & 0 & 0 \\
\hline Erythrotrichia carnea (Dillwyn) J. Agardh & 1 & 1 & 1 & 1 & 1 & 1 & 0 & 0 & 0 & 0 & 1 \\
\hline Fosliella farinosa (Lamouroux) Howe & 1 & 1 & 1 & 1 & 1 & 1 & 0 & 0 & 0 & 1 & 1 \\
\hline Galaxaura elongata $J$. Agardh & 1 & 1 & 1 & 1 & 0 & 1 & 0 & 1 & 0 & 0 & 0 \\
\hline * Galaxaura rugosa (Ellis et Sol.) Lamour. & 1 & 1 & 0 & 0 & 0 & 1 & 0 & 1 & 0 & 0 & 0 \\
\hline * Galaxaura schimperi Decaisne & 1 & 1 & 0 & 0 & 0 & 1 & 0 & 1 & 0 & 0 & 0 \\
\hline Gelidiella acerosa (Fors.) Feld. et Hamel & 1 & 1 & 1 & 0 & 0 & 1 & 0 & 1 & 0 & 0 & 1 \\
\hline Gelidium corneum (Hudson) Lamouroux & 1 & 1 & 1 & 0 & 0 & 0 & 0 & 1 & 0 & 0 & 1 \\
\hline Gelidium crinale (Turner) Lamouroux & 1 & 1 & 1 & 1 & 1 & 1 & 0 & 1 & 0 & 1 & 0 \\
\hline Gelidium pusillum (Stackhouse) LeJolis & 0 & 1 & 1 & 0 & 0 & 0 & 0 & 1 & 0 & 0 & 0 \\
\hline Gelidium spathulatum (Kützing) Bornet & 1 & 1 & 0 & 0 & 0 & 1 & 0 & 1 & 0 & 0 & 0 \\
\hline Goniotrichum alsidii (Zanardini) Howe & 1 & 1 & 0 & 0 & 0 & 1 & 0 & 0 & 0 & 0 & 1 \\
\hline Gracilaria arcuata Zanardini & 1 & 1 & 1 & 1 & 0 & 1 & 0 & 1 & 0 & 0 & 0 \\
\hline Gracilaria disticha (J. Agardh) J. Agardh & 1 & 1 & 0 & 0 & 0 & 1 & 0 & 1 & 0 & 0 & 0 \\
\hline * Gracilaria verrucosa (Hudson) Papenfuss & 0 & 1 & 0 & 0 & 0 & 1 & 0 & 1 & 0 & 0 & 0 \\
\hline Grateloupia filicina (Lamouroux) C. Agardh & 1 & 1 & 1 & 1 & 1 & 1 & 0 & 1 & 1 & 1 & 0 \\
\hline Griffithsia tenuis C. Agardh & 1 & 1 & 1 & 0 & 1 & 1 & 1 & 1 & 0 & 0 & 1 \\
\hline Herposiphonia secunda (C. Ag.) Ambronn & 1 & 1 & 0 & 0 & 0 & 1 & 0 & 0 & 0 & 0 & 1 \\
\hline Herposiphonia tenella (C. Ag.) Ambronn & 1 & 1 & 1 & 1 & 1 & 1 & 0 & 0 & 0 & 0 & 1 \\
\hline Heterosiphonia wurdemanni Falkenberg & 1 & 1 & 1 & 1 & 1 & 0 & 1 & 1 & 0 & 0 & 1 \\
\hline
\end{tabular}


Table 1. Continued.

\begin{tabular}{|c|c|c|c|c|c|c|c|c|c|c|c|}
\hline Hypnea cornuta (Kützing) J. Agardh & 1 & 1 & 1 & 1 & 1 & 1 & 0 & 1 & 1 & 1 & 0 \\
\hline Hypnea esperi Bory & 1 & 1 & 1 & 1 & 1 & 1 & 0 & 1 & 1 & 0 & 1 \\
\hline Hypnea musciformis (Wulfen) Lamouroux & 1 & 1 & 0 & 0 & 0 & 1 & 0 & 1 & 1 & 1 & 0 \\
\hline Hypnea valentiae (Turner) Montagne & 0 & 1 & 0 & 0 & 0 & 1 & 0 & 1 & 1 & 0 & 1 \\
\hline Jania adhaerens Lamouroux & 1 & 1 & 1 & 1 & 1 & 1 & 0 & 0 & 0 & 0 & 1 \\
\hline Jania pumila Lamouroux & 1 & 1 & 1 & 0 & 0 & 1 & 0 & 0 & 0 & 0 & 1 \\
\hline Jania rubens (Linnaeus) Lamouroux & 1 & 1 & 1 & 1 & 1 & 1 & 0 & 0 & 0 & 0 & 1 \\
\hline Laurencia obtusa (Hudson) Lamouroux & 1 & 1 & 1 & 1 & 0 & 1 & 0 & 1 & 0 & 1 & 0 \\
\hline Laurencia papillosa (C. Agardh) Greville & 1 & 1 & 1 & 1 & 1 & 1 & 0 & 1 & 0 & 0 & 0 \\
\hline * Laurencia pinnatifida (Hudson) Lamour. & 0 & 1 & 0 & 1 & 0 & 0 & 0 & 0 & 0 & 0 & 1 \\
\hline Leveillea jungermannioides Harvey & 1 & 1 & 1 & 1 & 1 & 1 & 0 & 0 & 0 & 0 & 1 \\
\hline Liagora farinosa Lamouroux & 1 & 1 & 0 & 1 & 1 & 0 & 0 & 1 & 0 & 0 & 0 \\
\hline * Liagora rugosa Zanardini & 0 & 1 & 0 & 1 & 0 & 0 & 0 & 1 & 0 & 0 & 0 \\
\hline Lithophyllum incrustans Philippi & 1 & 1 & 1 & 1 & 0 & 1 & 0 & 1 & 0 & 1 & 1 \\
\hline Lithophyllum pustulatum (Lamour.) Foslie & 1 & 1 & 1 & 1 & 1 & 1 & 0 & 1 & 0 & 1 & 1 \\
\hline Lomentaria irregularis Zanardini & 1 & 1 & 1 & 1 & 1 & 1 & 0 & 1 & 1 & 1 & 1 \\
\hline Lophosiphonia obscura (C. Ag) Falkenb. & 1 & 1 & 1 & 1 & 0 & 1 & 0 & 0 & 0 & 0 & 1 \\
\hline Lophosiphonia subadunca (Küt) Falkenb. & 1 & 1 & 0 & 0 & 0 & 1 & 0 & 0 & 0 & 0 & 1 \\
\hline Nitophyllum punctatum (Stack) Gerville & 1 & 1 & 1 & 0 & 0 & 1 & 0 & 1 & 0 & 1 & 0 \\
\hline Polysiphonia figariana Zanardini & 1 & 1 & 1 & 1 & 1 & 1 & 0 & 0 & 0 & 1 & 1 \\
\hline Polysiphonia variegata (C. Ag) Zanardini & 1 & 1 & 1 & 0 & 0 & 0 & 0 & 0 & 0 & 0 & 1 \\
\hline Porphyra umbilicalis (Linnaeus) J. Agardh & 1 & 1 & 1 & 0 & 0 & 1 & 0 & 1 & 0 & 1 & 0 \\
\hline Rhodymenia erythraea Zanardini & 1 & 1 & 1 & 0 & 0 & 1 & 0 & 1 & 0 & 0 & 0 \\
\hline Sarconema filiformis (Sonder) Kylin & 1 & 1 & 1 & 1 & 1 & 1 & 0 & 1 & 1 & 1 & 0 \\
\hline Solieria dura (Zanardini) Schmitz & 1 & 1 & 0 & 0 & 0 & 1 & 0 & 1 & 1 & 0 & 0 \\
\hline Spyridia aculeata (C. Ag. ex Dec.) Kützing & 1 & 1 & 0 & 0 & 0 & 1 & 0 & 0 & 0 & 0 & 1 \\
\hline Spyridia filamentosa (Wulfen) Harvey & 1 & 1 & 1 & 0 & 0 & 1 & 0 & 0 & 0 & 1 & 1 \\
\hline
\end{tabular}

The present list includes 15 new records, which are known as inhabitants of the Red Sea (El-Manawy and Gab-Alla, 2000). Many works have been concerned with the migration into and through the canal (Lipkin, 1972; Aleem, 1983; El-Manawy, 1992). All of these works suggested that both the northward current and the comparatively higher salinity of the canal have favored the migration of Red Sea species rather the Mediterranean ones.

The collected macroalgae comprised diverse forms, much of which were filamentous (e.g., Centroceras, Ceramium, Cladophora, Feldmannia, Griffithsia, Giffordia, Herposiphonia, Heterosiphonia and Rhizoclonium). These species were found epilithic on hard rocks and boulders or epiphytic on other larger algae. Some were turf forming (Gelidiella and Gelidium), fleshy sac-like (Valonia, Colpomenia, and Dictyosphaeria), foliose (Avrainvillea, Halimeda, Caulerpa, and Pocockiella) and the large brown algae (Cystoseira and Sargassum) were also found in the area. The repartition of algal flora into such diverse forms have been also recorded in many areas on the coral reefs of the Red Sea (El-Manawy and Gab-Alla, 2000) and in the Mediterranean at Alexandria (Aleem, 1993). Caulerpa, Cladophora and Enteromorpha were the best represented genera among the green algae, as they contributed to this group by 7, 5 and 5 species, respectively (Table 1). In comparison with the reef habitats of Red Sea (Hegazy, 1992), these three genera are quite common and much more abundant in the Suez Canal. Calcified green algae were less common in the canal, and this is in contrast with reef 
community described by El-Manawy and Gab-Alla (2000) at Shalateen in the Red Sea, as these algae are dominant. Dictyota, Sargassum, Ceramium, Chondria, and Gelidium were represented by 3 to 5 species but they formed small patches among the vegetation of the canal.

The characteristics of algal community, such as the spatial, zonal, seasonal and substrata variations are presented in Tables 1 and 2, and Figures 2 and 3. Cluster analysis of the sixteen sampled sites, based on co-occurrence of all investigated algae, gave five groups of sites at a level of about 6.5 of euclidean distance (Figure 2). The first group includes Kabrit and Deversoir that lay on the southern and northern ends of the Great Bitter Lake. They were the more hospitable sites in the canal, as they contained 74 and 86 species, respectively (Table 2). The hospitality of these sites may be attributed to the availability of wide variety of algal habitats with soft and hard, sheltered and exposed, lightened and shaded substrata. The second group includes el-Shallufa, Port Taufiq and Gineifa, which represent the southern part of the canal. They contained 40-44 species that are frequently known in the Red Sea and Gulf of Suez (Papenfuss, 1968; El-Manawy and Gab-Alla, 2000).

Table 2. Contribution of algal groups in different years, sites, seasons, and substrata.

\begin{tabular}{|c|c|c|c|c|c|}
\hline \multirow{2}{*}{ Variables } & \multirow{2}{*}{ Details } & \multicolumn{4}{|c|}{ Number of taxa } \\
\hline & & Chlorophyta & Phaeophyta & Rhodophyta & Total \\
\hline \multirow{2}{*}{ Years } & Year 1996 & 34 & 19 & 62 & 115 \\
\hline & Year 2000 & 36 & 22 & 69 & 127 \\
\hline \multirow{16}{*}{ Sites } & Port Said & 20 & 8 & 26 & 54 \\
\hline & Ras el-Ish & 12 & 6 & 20 & 38 \\
\hline & el-Tina & 14 & 7 & 15 & 36 \\
\hline & el-Kab & 13 & 5 & 18 & 36 \\
\hline & el-Qantara & 18 & 11 & 23 & 52 \\
\hline & el-Ballah & 11 & 6 & 20 & 37 \\
\hline & el-Ferdan & 12 & 5 & 18 & 35 \\
\hline & Ismailia & 18 & 5 & 25 & 48 \\
\hline & Toussoun & 15 & 9 & 21 & 45 \\
\hline & Deversoir & 17 & 11 & 46 & 74 \\
\hline & Faied & 11 & 9 & 33 & 53 \\
\hline & Fanara & 14 & 9 & 30 & 53 \\
\hline & Kabrit & 24 & 13 & 49 & 86 \\
\hline & Gineifa & 10 & 12 & 18 & 40 \\
\hline & el-Shallufa & 10 & 11 & 19 & 40 \\
\hline & Port Taufiq & 13 & 14 & 17 & 44 \\
\hline \multirow{4}{*}{ Seasons } & Spring & 32 & 15 & 45 & 92 \\
\hline & Summer & 25 & 11 & 41 & 77 \\
\hline & Autumn & 13 & 8 & 29 & 50 \\
\hline & Winter & 29 & 19 & 55 & 103 \\
\hline \multirow{5}{*}{ Substrata } & Sand & 14 & 1 & 4 & 19 \\
\hline & Concrete & 21 & 19 & 43 & 83 \\
\hline & Boulders & 10 & 2 & 13 & 25 \\
\hline & Wracks & 11 & 4 & 17 & 32 \\
\hline & Epiphytes & 16 & 5 & 40 & 61 \\
\hline
\end{tabular}




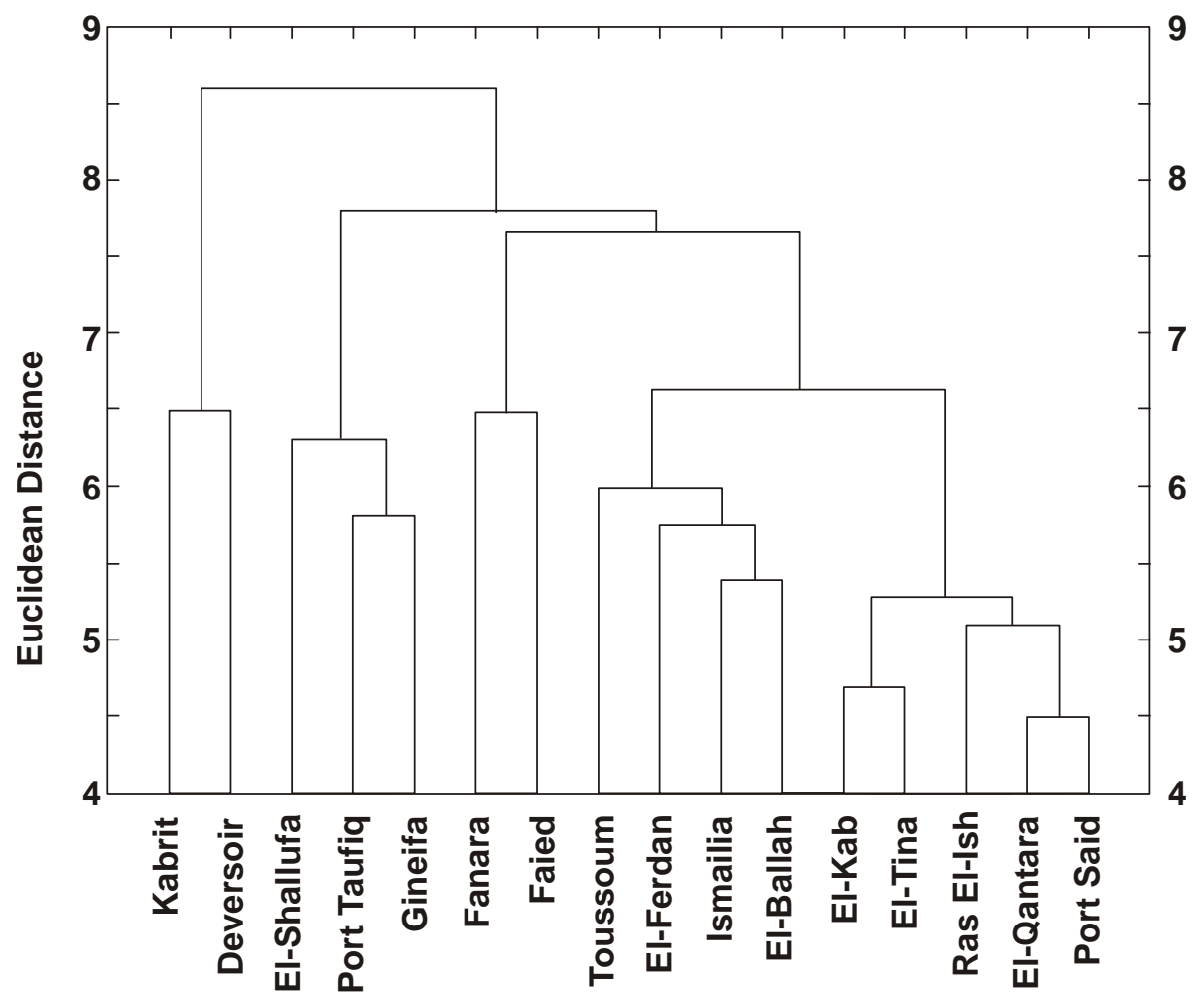

Figure 2. Dendogram showing results of cluster analysis of sites using euclidean distance as a similarity coefficient.

The third group includes Fanara and Faied that lay near the middle part of the Great Bitter Lake and represented by the mooring posts and some ship wracks and extensively exposed to wave created by the passage of ships. Although the space available for algae is relatively small in such habitat, 53 species were found in each site. Most of these species were small in size, when compared with the same species in other habitats in the canal, or found as epiphytes. Laurencia papillosa and Sargassum subrepandum were only the larger forms found there. The increased number of smaller forms with the epiphytism may demonstrate how macroalgae have attempted to solve the space problem in these sites.

The fourth group includes Toussoun, el-Ferdan, Ismailia and el-Ballah that lay around the Lake Timsah and contained 35-48 taxa. The fifth group includes el-Kab, elTina, Ras el-Ish, el-Qantara and Port Said. They contained 36-54 species, most of which are known in the Eastern Mediterranean (Aleem, 1993).

The resulted site groupings may suggest division of Suez Canal into four biological sectors. From a hydrographic point of view, many authors (El-Sabh, 1969; Hassan and El-Sabh, 1974) have divided the canal into three to four parts, which are greatly related to the present site groupings. According to El-Sabh (1969), the northern section of the canal always contains some Mediterranean water, there is a surface layer of 
low salinity always existing in the Lake Timsah, the Bitter Lakes has a high salinity, the southern section is affected by the tidal cycle at Port Taufiq. The present values of salinity assist this suggestion.

The algal community of the canal also showed a great seasonal variation in floristic composition (Tables 1 and 2). Forty species were found all the year round. These could be considered as ephemerals, as they can rapidly developed and produced several annual generations. Among these, the following taxa were the most ecologically important species in the canal in view of their prominent dominance and dense growth: Chaetomorpha indica, Cladophora crystallina, C. prolifera, Cladophoropsis zollingeri, Enteromorpha clathrata, E. intestinalis, E. prolifera, and Ulva lactuca from Chlorophyta; Cystoseira myrica, Dictyota dichotoma, Padina pavonica, and Sargassum subrepandum from Phaeophyta; Acanthophora najadiformis, Ceramium taylorii, Grateloupia filicina, Hypnea cornuta, Laurencia papillosa, Lomentaria irregularis, Polysiphonia figariana, and Sarconema filiformis from Rhodophyta.

The maximum number of species was found in winter (103 species), followed by spring (92 species). Most new records were found during these two seasons. They appeared to be the favorable period of algal migration and development. El-Manawy (1992) suggested that the low water temperature, low salinity and northward current in these seasons share for algal migration. In summer, the number of species was 77, decreased to the minimum during autumn (50 species).

The distribution of macroalgae along the depth gradient is depicted in Figure 3 for the ephemeral species. Derbesia lamourouxii and Porphyra umbilicalis were seen as characteristic species of the upper zones, so they were added to illustrate the depth variation. The supralittoral zone was poorly developed and this may reflect the effect of air temperature. In winter, a mixed community of filamentous blue green algae with Cladophora rupestris and Derbesia lamourouxii dominating this zone near the main navigation channel, being supported by excess water due to passage of ships.

The algae distributed in the littoral zone were mainly Chlorophyta and Rhodophyta. In the field, the upper limit of Cladophoropsis zollingeri and the lower limit of Bangia fuscopurpurea can discern the littoral zone. The height of this zone was between 15 and $50 \mathrm{~cm}$, and the distribution of algae within it seems to be dependent upon tidal range, exposure and substrata. The tidal range in the canal has an amplitude of about $55 \mathrm{~cm}$ (see Morcos and Gerges, 1974).

Infralittoral zone was permanently submerged and thus contained a large number of seaweeds. The distribution of algae in this zone extended to about $240 \mathrm{~cm}$, sometime more when the substrata were available. A mixed community of green, brown and red algae were found at a depth between $30-150 \mathrm{~cm}$, while only several species of red algae with Caulerpa racemosa were found deeper. The rarity of algae below $150 \mathrm{~cm}$ deep may be attributed to low water clarity in the canal. Laurencia papillosa formed a dense population in all depths of infralittoral. El-Manawy (1992) studied the distribution of this alga along the gradient of different ecological parameters. He concluded that the alga seems to be tolerant to most extreme conditions. 


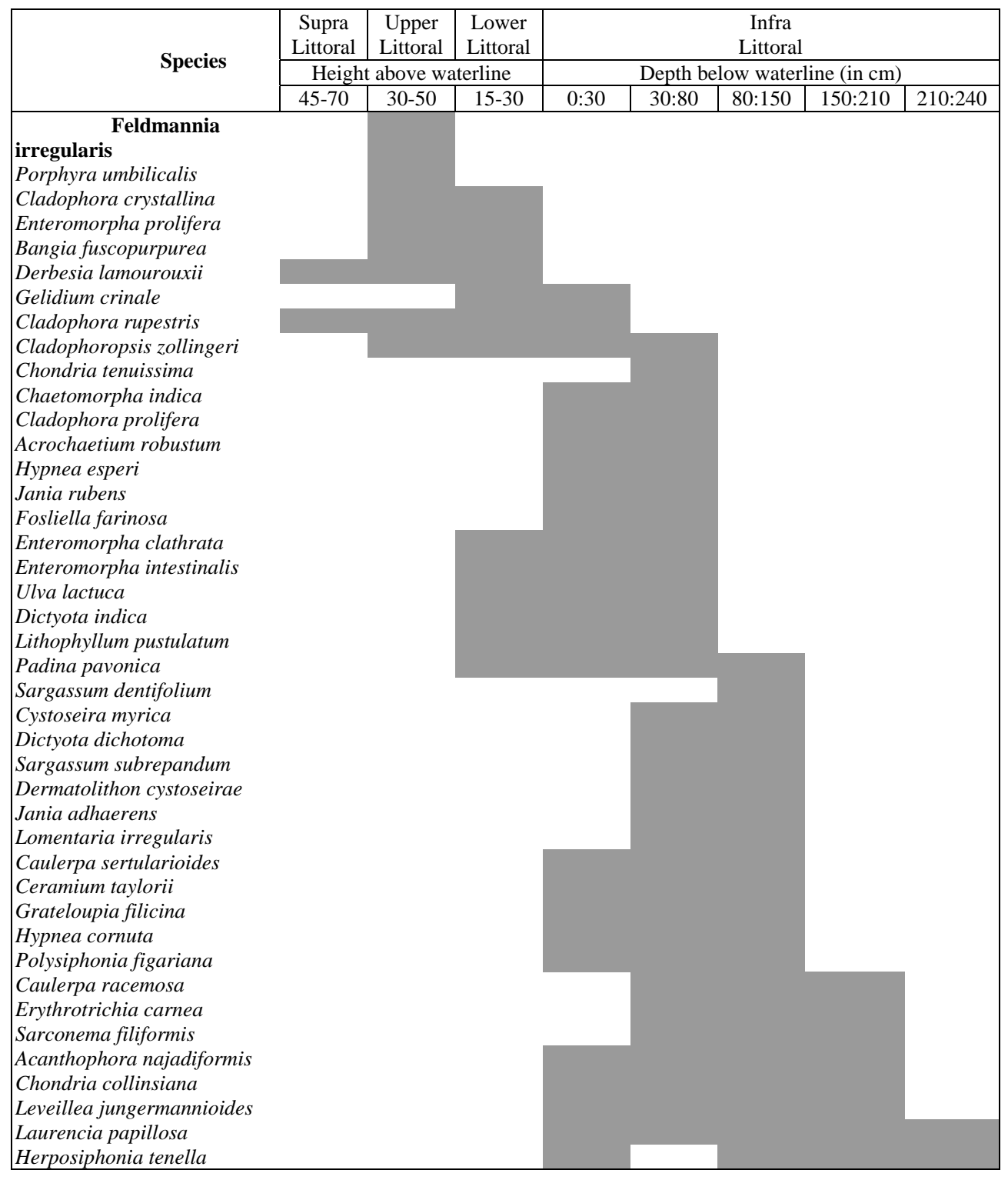

Figure 3: Zonation of the common algae in relation to hydrodynamic zones of the Suez Canal.

Substrata played an important role for settlement and distribution of algae in the canal, and this was evident and recognized by the richness or poverty of the algal populations. The natural sandy shores of the lakes were generally devoid of macroalgae. The stones, pebbles and the small boulders on these shores give way for the settlement of some algae especially the filamentous green ones (Table 1). The sandy bottom, near the canal embankments at a depth of about $150 \mathrm{~cm}$, supports several psammophytic algae. 
Only 19 species, including 14 green, one brown and four red algae were found on this sandy substratum (Table 2). Ship wracks and other hard substrata in marinas, harbor walls, canal embankments, and pilings supported distinctly zoned algal communities. The concrete pavements are the common substrata in all parts of the canal. They supported 83 species of the investigated algae, while boulders and wracks supported 25 and 32 species, respectively.

In comparison with the open shores of the Red Sea or the Mediterranean, the substrata in the Suez Canal provide small space for the settlement of algae. As mentioned earlier, the depth distribution of algae was generally restricted to about $240 \mathrm{~cm}$. Moreover, the horizontal distance from the above waterline to the lowest point of algal distribution rarely reached 10 meters. The competition for space was evident by the number of smaller macroalgal forms and by the number of epiphytes found in all sites. Sixty-one species of epiphytes was found during this study (Tables 1 and 2). More than a half of these were also found on the other hard substrata when the space was available. Several large seaweeds, such as the species of Acanthophora, Cystoseira, Hypnea, Laurencia papillosa, Padina and Sargassum subrepandum serve as basiphytes for the epiphytic macroalgal communities.

\section{Succession of macroalgal flora in the Suez Canal}

To follow up the colonization and succession of macroalgae in the canal, the lists given by Aleem (1980) and Farghaly (1985) with the present list are the more convenient, as they seem to be the most intensive collections ever made along the whole length of the canal (Figure 4). Although each of the other algal reports revealed new records of species, they were less intensive, had spatial and seasonal limitations.

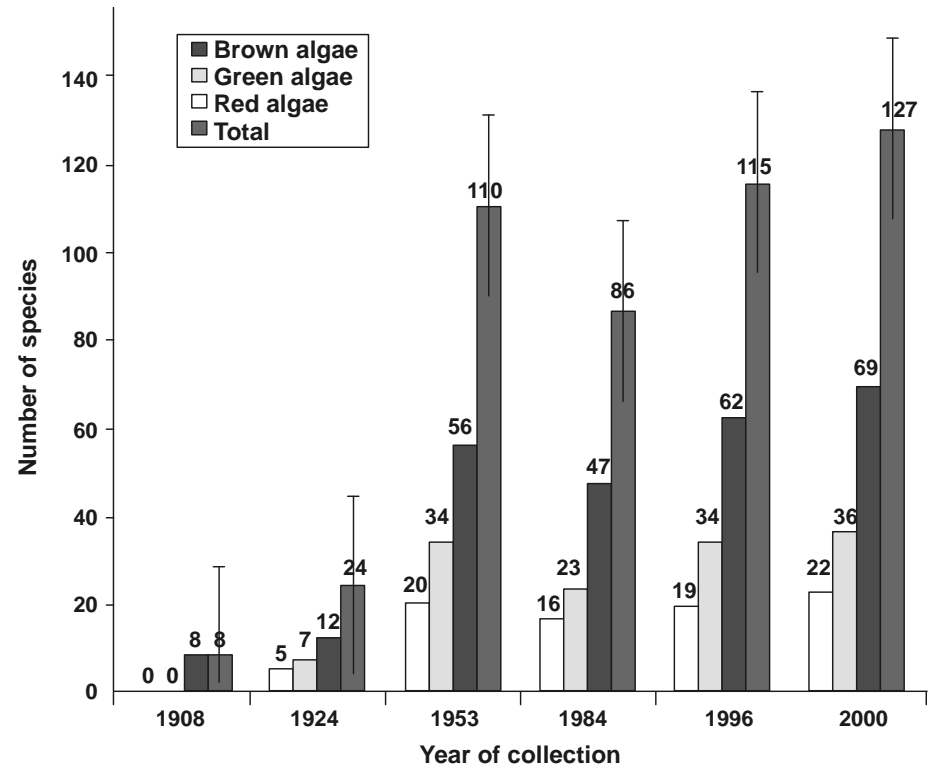

Figure 4. Contributions of algal groups and the total number of species in different years of collection. The bar indicates \pm standard error 
With the present list, the number of macroalgae colonized the Suez Canal is raised to 168 species. Fifty species were the members of Chlorophyta, 29 of Phaeophyta and 89 of Rhodophyta. Aleem (1980) collected a mixed community of 110 taxa of 34 green, 20 brown and 56 red algae in 1953. The macroalgal community of the canal probably passed through several successional stages and reached a climactic stability before that time. Doty (1957) recorded a climax community of microalgae and macroalgae on the newly formed rock 10 years after a lava flow in Hawaii. Duggins (1980) recorded a similar climax after three years in Torch Bay, Alaska. The time needed for the establishment of a climax community in the canal may be longer than that given by Doty. The reason for this could be the hyper-salinity of water that may have prevented a greater number of species from migration. The salinity was measured as 70\%o in 1870 and 57\% in 1930 (Por, 1978), and only the euryhaline species have had the chance to migrate from the adjacent seas into the canal. Muschler (1908) reported only eight of red species. The simplest forms of green algae are usually the pioneers in the newly colonized marine environment (Williams, 1990). Ulva, Enteromorpha and Cladophora are excellent examples (El-Manawy, unpublished data), and known as euryhaline genera (Dawes et al., 1978). Species like these should be found as a part of the pioneers in Muschler's list. In 1924, Fox (1926) collected 24 species of green, brown and red algae, and declared that the diversity of species was still low, but the species occupied different biotopes and had facilitated the hard and soft substrata for new colonizers.

The salinity, in 1953, was 35.4 - 40.5\% in the northern part of the canal, 49\%o in the Bitter Lakes, and 43\%o in Port Taufiq (Aleem, 1983). By 1965, the salinity barrier was completely uplifted by the dissolution of the salt bed of the Great Bitter Lake, whereas the water salinity did not greatly depart from that measured in 1953 (see Study area). This may support again the idea that the canal flora reached a climatic stability corresponding to the stability of salinity conditions in 1953.

The climax that was probably established in 1953 may have become degraded due to war conditions and the partial closure of the canal of June 1967. Unfortunately, no phycological work could attest for algal succession during this period. In 1969, Lipkin (1972) collected only 55 macroalgal taxa. The Lipkin's list could be incomplete, as he collected algae within few hours from few localities on the eastern shores of the middle part of the canal during the war conditions.

The navigation channel had been widened and deepened during the period from 1973 to 1985; and the turn over of canal bottom affect again the stability of macroalgal flora. Works such as building of ports, harbors, jetties, and revetments increased the stress on algae. Moreover, the voluminous discharge of thermal, domestic and agricultural effluents into the canal could have disrupted the successional progression of macroalgae and the process restarted at some earlier stage. This argument could be arrived at looking at the list given by Farghaly (1985). Forty-eight of the species that were found in 1953 had been lost during the period to 1984 . Twenty-three of these species re-colonized the canal and were found during this study.

Studies of marine environments suggest that the recovery of macroalgal communities is a result of succession (Williams, 1990), competition (Stewart, 1989), grazing (Little and Kitching, 1996) and improvement of the habitat (Littler and Littler, 1980). At the end of 1995, navigation and its accompanied works have been reduced in the canal. Treatment plants of sewage and other effluents were constructed and the industrialization and urbanization effluents are therefore limited. Thus, the improvement 
in algal habitats has enhanced an increase of re-colonization and immigration. The nearstability of algal community or the climax could be found by the year 2000 .

Improvement of habitats not only ameliorates the species composition but also modifies their dominance. Whereas, El-Manawy (1992) reported a dense coverage and biomass for Cladophora, Enteromorpha, Ulva, and Grateloupia at the areas of domestic effluents, a reduction in the dominance of these species was seen during this study. Limited distribution and poverty of brown algae previously characterized the polluted areas of the canal (El-Manawy, 1987, 1992). Now, a mixed community of green, red and brown algae was observed along the whole length of the canal. Exception was found in area of motorboats at Suez, where the Colpomenia sinuosa was observed to form semipure gross stands due to oil pollution.

It is interesting to note that about one third of species were recorded during the period from 1953 to 2000 and are well established in the canal even when the conditions have been changed. Most of these species are known as cosmopolitans with wide distribution in both temperate and tropical waters (El-Manawy, 1992), e.g., Caulerpa racemosa, Chaetomorpha indica, C. linum, Cladophora albida, Ulva lactuca and the species of Enteromorpha.

In conclusion, the succession of macroalgae in the Suez Canal could have developed in four stages. The early stage included the pioneer species that were recorded in 1908 and 1924. The second represented a mature climax stage reached in 1953 and correspond to the near stability of salinity conditions. The third stage represented certain degradation in the algal community during the period of disturbances in the canal. The later stage has been reached in the year 2000 and represents the reestablishment of the climax with the new improvement in algal habitats.

\section{References}

Aleem, A. A., 1980. Contribution to the study of the marine algae of the Red Sea. IV. The algae and seagrasses inhabiting the Suez Canal. Bull. Fac. Sci.K. Abdle Aziz Uni., Jeddah, 4:31-89.

Aleem, A. A., 1983. The Suez Canal as a habitat and pathway for marine algae and seagrasses. Pro. Mabahith John Murray Int. Symp., Egypt., 3-6 September: 907918.

Aleem, A. A., 1993. The marine algae of the Alexandria, Egypt. Uni. of Alexandria, Egypt.

Beets, C., 1953. Notes on dredging in the Great Bitter Lake of the Suez Canal. Zool. Meded. Rijksmus. Nat. Hist. Leiden, 32: 9-106.

Børgesen, F., 1920. Marine algae from Easter Island. Uppsala, Almqvist Wiksells, 2:249309

Børgesen, F., 1925-1936. Marine algae from the Canary Islands Biol. Med. Dan. Vid., Selsk, 1925, 5:1-123; 1926, 6: 1-112; 1927, 6:1-97; 1929, 8:1-97; 1930, 9:159; 1936, 12:1-43

Børgesen, F., 1944-57. Some marine algae from Mauritius. Biol. Med. Dan. Vid., Selsk. 1944, 19:1-32; 1945, 19:1-68; 1948, 20:1-55; 1949, 21:1-48; 1950, 18:1-46; 1950, 19:1-10; 1951, 18:1-44; 1952, 18:1-72; 1953, 21:1-62; 1954, 22:1-51; 1957, 23:113. 
Dawes, C. J., Moon, R. E., and Davis, M. A., 1978. The photosynthetic and respiratory rates and tolerances of benthic algae from a mangrove and salt marsh estuary: A comparative study. Estuar. Coast. Mar. Sci., 6: 175-185.

Dawson, E.Y., 1962. New taxa of benthic green, brown and red algae. Beaudette Found., Santo Ynez, California.

de Lesseps, F., 1876 . Deuxieme communication sur les lacs amers de l'Isthme de Suez. Comm. Acad. Sci. Paris, 82: 1135-1138.

Doty, M.S., 1957. Rocky intertidal surfaces. Geol. Soc. Amer. Memoir, 67:315-585.

Duggins, D.O., 1980. Kelp beds and sea otters. An experimental approach. Ecol., 61:447453.

El-Manawy, I. M., 1987. Ecological studies on the seaweeds of the Suez Canal. M.Sc. thesis, Fac. Sci., Suez Canal Uni., Ismailia, Egypt.

El-Manawy, I. M., 1992. Ecological studies on the marine benthic flora of the Bitter Lakes (Suez Canal). Ph.D. thesis, Fac. Sci., Suez Canal Uni., Ismailia, Egypt.

El-Manawy, I. M., and Gab-Alla, A., 2000. Distribution and biodiversity of seaweeds on coral reefs at Shalateen-Halaib sector (Red Sea, Egypt). Pro. $1^{\text {st }}$ Inter. Conf. Biol. Sci. (ICBS) Fac. Sci., Tanta Univ., 7-8 May-2000, 7: 73-87.

El-Sabh, M. I., 1969. Seasonal hydrographic variations in the Suez Canal after the completion of the Aswan High Dam. Kiel. Meeresforsch, 1: 1-18.

El-Soubaky, G., 1995. Ecophysiological studies on some seaweeds of the Suez Canal. Ph.D. thesis, Fac. Sci., Suez Canal Uni., Ismailia, Egypt.

Farghaly, M. S., 1985. Remarks on the marine vegetation of the Suez Canal. Botanical Soc. $4^{\text {th }}$, (Ismailia conf.), Egypt.:1377-1391.

Farghaly, M. S., El-Manawy, I. M., and Denizot, M., 1988. Floristic and seasonal variations of the seaweed communities in the lake Timsah (Suez Canal). Naturalia monspeliensia, 53: 75-108.

Feldmann, J., 1940. Recherche Sur les Ceramiacees de la Mediterranee-Occidentale. Alger.

Fox, H.M., 1926. Cambridge Expedition to the Suez Canal, 1924. General.Part. Trans. Zool. Soc. Lond., 22: 1-64.

Gruvel, A., 1932. Contribution a l'etude de la Bionomie generale et de l'exploitation de la Fauna du Canal du Suez. Mem. Inst. Egypte, 29: 1-255.

Hassan, E. M., and El-Sabh, M. I., 1974. Change in the current regime in the Suez Canal after construction of Aswan High Dam. Nature, 218:758-760.

Hegazy, M. M., 1992. Ecological studies on the seaweeds of south Sinai. M.Sc. thesis. Fac. Sci. Suez Canal Uni.

Jaasund, E., 1977. Marine algae in Tanzania. Bot. Mar., 20:509-520.

Jaccard, P., 1908. Nouvelles recherches sur la distribution floral. Bull. Soc. Vaud. Sci. Nat., 44: 223-270.

Lami, R., 1932. Quelques algues du grand lac Amer (Basse Egypte) recoltees par M. le Professeur Gruvel, en Avril 1932. Rev. Algol., 6: 355-356.

Lipkin, Y., 1972. Marine algal and seagrass flora of the Suez Canal. Isr. J. of Zool., 21:204-445.

Little, C., and Kitching, J.A., 1996. The biology of Rocky Shores. Oxford Univ. Press, Oxford.

Littler, M., and Littler, D., 1980. The evolution of the thallus form and survival stratigeies in benthic marine macroalgae: Field and laboratory tests of a functional form model. Amer. Nat. 116:25-44. 
Lyle, L., 1930. Algae of the Suez Canal. J. Bot. London, 68:327-334

Miller, A.R., and Munns, R.G., 1974. The Bitter lake salt barrier. L'Oceanographie Physique de la Mer Rouge Symp.in Assoc., Inst. Sci. Phys. Ocean. CNEXO, 2: 395309.

Morcos, S.A., and Gerges, M.A., 1974. Circulation and mean sea level in the Suez Canal. In: L'Oceanographie physique de la Mer Rouge, IAPSO UNESCO-SCOR Symp. Paris 1972. CNEXO Pub. Ser. Actes Collq., 2:267-287.

Muschler, R., 1908. Enumeration des algues marines et d'eau douce observees jusqu'a ce jour en Egypte. Memoires de l'Institut d'Egypte, 5: 141-237.

Papenfuss, G. F., 1968. A history, catalogue and bibliography of Red Sea benthic algae. Isr. J. Bot., 17:1-119.

Por, F. D., 1978. Lessepsian Migration. Springer Verlag Berlin Heidelberg.

Stewart, J. G., 1989. Maintenance of a balanced, shifting boundary between the seagrass Phyllospadix and algal turf. Aquat. Bot., 33:223-241.

Williams, S. L., 1990. Experimental studies of Caribbean seagrass bed development. Ecol. Monograf., 60:449-469.

Wüst, G., 1934. Salzgehalt und Wasserbewegung im Suez Kanal. Naturwissensch., 22:446-450. 